\title{
Pasture production under different irrigation depths
}

\author{
Laísa S. Antoniel ${ }^{1}$, Giuliani do Prado $^{1}$, Adriano C. Tinos ${ }^{1}$, \\ Gabriel A. Beltrame ${ }^{1}$, João V. C. de Almeida ${ }^{1} \&$ Gustavo P. Cuco $^{1}$ \\ ${ }^{1}$ Universidade Estadual de Maringá/Campus do Arenito/Departamento de Engenharia Agrícola. Cidade Gaúcha, PR. E-mail: lala_scotti@hotmail.com; \\ gprado@uem.br (Corresponding author); actinos@uem.br; gbeltrame@hotmail.com; juaovitor1996@hotmail.com; gupc_tdb@hotmail.com
}

\section{Key words:}

Brachiaria brizantha

Panicum maximum

evapotranspiration

\begin{abstract}
A B S T R A C T
This study aimed to evaluate the production of two pasture species, Brachiaria brizantha cv. BRS Piatã and Panicum maximum cv. Mombaça, under different irrigation depths. The experiment was carried out from May to December 2014, at the State University of Maringá, in the municipality of Cidade Gaúcha-PR, Brazil. The experiment was set out in a strip-plot design, with four replicates, six irrigation depths in the plot and two pasture species in the subplot. Irrigation depths were represented by a percentage of reference evapotranspiration $\left(\mathrm{ET}_{0}\right)$, which was estimated by the Penman-Monteith equation. Four pasture cuts were performed during the studied period and there were no differences between the yields of both evaluated pasture species; however, irrigation depths caused a quadratic response on pasture yield. The maximum values of dry matter yield of the pastures under irrigated conditions were 52.1, 41.6, 26.2 and 25.1\% higher than under non-irrigated conditions, for the $1^{\text {st }}, 2^{\text {nd }}, 3^{\text {rd }}$ and $4^{\text {th }}$ cuts, respectively. Irrigation depths that applied water volumes close to $\mathrm{ET}_{0}$ promoted considerable increases in pasture yield.
\end{abstract}

Palavras-chave: Brachiaria brizantha Panicum maximum evapotranspiração

\section{Produção de pasto com diferentes lâminas de irrigação}

\section{R E S U M O}

Objetivou-se, neste trabalho, avaliar a produção de duas espécies de pastagens, Brachiaria brizantha cv. BRS Piatã e Panicum maximum cv. Mombaça, submetidas a diferentes lâminas de irrigação. O experimento foi conduzido entre os meses de maio a dezembro de 2014, na Universidade Estadual de Maringá (UEM), em Cidade Gaúcha, PR. O delineamento experimental, com quatro repetições, foi em parcelas subdivididas em faixas com seis lâminas de irrigação na parcela e as duas espécies de pastagens na subparcela. As lâminas de irrigação foram constituídas por valores percentuais da evapotranspiração de referência $\left(\mathrm{ET}_{0}\right)$ calculada pela equação de Penman-Monteith. No período foram realizados quatro ciclos de corte observando-se que não houve diferença na produção entre as duas pastagens e que as respostas produtivas às lâminas de irrigação foram quadráticas. Ao comparar a produção máxima de matéria seca proporcionada pela irrigação com os valores produtivos não irrigados observaram-se, respectivamente para os $1^{\circ}, 2^{\circ}, 3^{\circ}$ e $4^{\circ}$ cortes, valores de 52,1 , $41,6,26,2$ e 25,1\% maiores que a produção de sequeiro. Lâminas aplicadas próximas a $\mathrm{ET}_{0}$ proporcionaram aumentos consideráveis na produtividade das pastagens. 


\section{INTRODUCTION}

Since bovines are ruminants, pastures have great relevance in the feeding of these animals due to the practicality and economy in their production (Cunha et al., 2007; Santos et al., 2009). However, it is known that the economic results that have been obtained by the majority of cattle farmers are below the production potential of the forages (Vitor et al., 2009). Thus, it is notorious the need to intensify pasture production in order to produce greater amounts in smaller pasture areas.

The decrease in forage production during the dry period has been a very emphasized topic in the research on grass species used for grazing. According to Ribeiro et al. (2009), the seasonality of forage production in the dry period is related to soil fertility, temperature, luminosity and the amount of available water. In this context, irrigation is one alternative to minimize yield losses caused by prolonged droughts and seasonality.

The productive increment in irrigated pastures, compared with rainfed cultivation, is evidenced by many authors (Müller et al., 2002; Gomes et al., 2015; Sanches et al., 2015). Research results have demonstrated the possibility of maintaining, in irrigated pastures during the dry period, 40 to $50 \%$ of the animal stocking rate that is maintained in the spring/summer, while these values comprehend only 10 to $20 \%$ in the absence of irrigation (Alvares, 2001).

Studies related to the productive response of pastures to different irrigation depths are more scarce in the literature. There is a lack of studies relating water regimes of pastures that subsidize the choice of the irrigation system and its management. Thus, this study aimed to evaluate fresh and dry matter production of two pasture species subjected to different irrigation depths.

\section{Material AND Methods}

The experiment was carried out on the Campus of Arenito, municipality of Cidade Gaúcha, in the Northwest region of Paraná, Brazil (2322’ 30” S; 52 56’00” W; 404 m). The climate in the region is mesothermal humid subtropical, according to Köppen's classification, which has hot summers with tendency of concentration of rains, mean annual temperature of 22 ${ }^{\circ} \mathrm{C}$ and winters with infrequent frosts, without a defined dry season.

The soil in the experimental area is classified as sandy-textured dystrophic Red Latosol and its chemical characterization before installing the experiment, for the layer of $0-0.20 \mathrm{~m}$, was performed at the Laboratory of Soils and showed the following results: $\mathrm{pH}$ in water $=6.0 ; \mathrm{pH}$ in $\mathrm{CaCl}_{2}=5.3 ; \mathrm{H}+\mathrm{Al}=2.54 \mathrm{cmol} \mathrm{dm}_{\mathrm{c}}^{-3}$ (SMP method); $\mathrm{Al}^{3+}=0.00 \mathrm{cmol}_{\mathrm{c}} \mathrm{dm}^{-3}, \mathrm{Ca}^{2+}=0.59 \mathrm{cmol}_{\mathrm{c}} \mathrm{dm}^{-3}$, $\mathrm{Mg}^{2+}=0.18 \mathrm{cmol}_{c} \mathrm{dm}^{-3}$ (extracted with $1 \mathrm{~mol} \mathrm{~L}^{-1} \mathrm{KCl}$ ); $\mathrm{K}^{+}=0.22$ $\mathrm{cmol}_{\mathrm{c}} \mathrm{dm}^{-3}, \mathrm{P}=13.8 \mathrm{mg} \mathrm{dm}^{-3}$ (extracted with Mehlich 1) and C $=2.80 \mathrm{~g} \mathrm{dm}^{-3}$ (Walkley and Black method).

In order to increase soil base saturation to $60 \%$ and according to the recommendations for pastures of the Agronomic Institute of Paraná - IAPAR (Oliveira, 2003), six months before installing the experiment, dolomitic limestone (RNV 85\%) was applied at the dose of $1,327 \mathrm{~kg} \mathrm{ha}^{-1}$, based on the results of soil chemical analysis.
The experiment with four replicates was set in strip-plot scheme, with six irrigation depths in the plot and two pasture species in the subplot. The factor irrigation depth consisted of a zero depth (I0), a depth of replenishment of reference evapotranspiration - $\mathrm{ET}_{0}$ (I3) and two values below (I1 and I2) and above (I4 and I5) the depth I3, whereas the factor pasture consisted of the species Brachiaria brizantha cv. BRS Piatã (P) and Panicum maximum cv. Mombaça (M). Thus, the experiment had 48 experimental units, each one with dimension of $2 \times 4 \mathrm{~m}$, and the pastures were randomly distributed inside each strip.

In May 2014, pastures were manually sown at the depth of $0.03 \mathrm{~m}$, in rows, and spaced by $0.20 \mathrm{~m}$. As basal fertilization, $10 \mathrm{~kg} \mathrm{ha}^{-1}$ of $\mathrm{P}_{2} \mathrm{O}_{5}$ and $20 \mathrm{~kg} \mathrm{ha}^{-1}$ of $\mathrm{K}_{2} \mathrm{O}$ were applied at sowing, according to the recommendations for pastures of the IAPAR (Oliveira, 2003). For better uniformity, $60 \mathrm{~kg} \mathrm{ha}^{-1}$ of nitrogen were diluted in water and applied as top-dressing using a watering can. This application was divided into two doses, one before the first cut (June 24, 2014) and another after the second cut (October 3, 2014).

At the beginning of the experiment, irrigations were performed to meet pasture water requirements in all experimental units. From the germination and development of the pastures, thinnings were performed in order to standardize the number of plants in the subplots. According the recommendations of Alencar et al. (2010), the experimental units of Piatã and Mombaça were established with populations of 20 and 40 plants $\mathrm{m}^{-2}$, respectively.

Irrigation depth treatments were differentiated 73 days after sowing and one line of sprinklers spaced by $12 \mathrm{~m}$ in the row was left on one end of the experimental area. Since the sprinkler NY30 (Agropolo ${ }^{\varpi}$ ), with nozzles of $5.0 \times 4.6 \mathrm{~m}$, at the pressure of $275 \mathrm{kPa}$, has radial water distribution profile that tends to the triangular geometric form, the irrigation depth of $100 \%$ of reference evapotranspiration (I3) was established in the central strip. Thus, the treatments with lowest irrigation depths (I0, I1 and I2) and highest irrigation depths (I4 and I5) were defined during the allocation of the I3 treatment.

Irrigation management was performed based on climatological data from the weather station of the National Institute of Meteorology (INMET), installed $50 \mathrm{~m}$ distant from the experimental area. Data of incident radiation, minimum, medium and maximum temperature, wind speed at $10 \mathrm{~m}$ from the soil and relative air humidity were daily obtained from the INMET website, for the estimation of reference evapotranspiration $\left(\mathrm{ET}_{0}\right.$ ) by the Penman-Monteith equation.

The value of net water depth, determined by the sum of $\mathrm{ET}_{0}$ minus the rainfall, was fully applied in the treatment I3, at intervals of 3 to 5 days. In the control of the irrigation depths applied in the treatments, the amounts of water were collected in water collectors with diameter of $0.08 \mathrm{~m}$, placed at a height of $0.95 \mathrm{~m}$ from the soil surface. Four lines of collectors positioned between two central sprinklers and transversely to the direction of the experimental strips were used to determine the water depth applied in each treatment.

Pasture cuts were performed in the first hours of the morning using garden shears in the time interval from 30 to 40 days. Inside each experimental unit, a rectangular metal 
frame $(1.0 \times 2.0 \mathrm{~m})$ was placed in the center of the area, at a height of $0.33 \mathrm{~m}$ from the soil surface, for sample collection and packaging, in plastic bags. After collecting the samples of each experimental unit, the borders were mowed using a backpack mower.

The collected pasture samples were taken to the laboratory and weighed for the determination of fresh matter. Then, half of the fresh matter of each sample was placed in paper bag and taken to a forced-air oven at $65^{\circ} \mathrm{C}$ for $72 \mathrm{~h}$, in order to obtain the dry matter.

The treatments were subjected to analysis of variance at 0.05 probability level by $\mathrm{F}$ test. Qualitative and quantitative variables were compared by Tukey test at 0.05 probability level and regression analysis, respectively. All the statistical analyses were performed using the program Sisvar version 5.3 (Ferreira, 2011).

\section{Results AND Discussion}

Data of mean temperature (Tm), incident radiation $(\mathrm{Rd})$, rainfall $(\mathrm{P})$ and $\mathrm{ET}_{0}$, from May to December, are shown in Figure 1. Irrigation guaranteed germination and the formation of pastures, since there were no rains from sowing to treatment differentiation. In the periods between the first, second, third and fourth cuts, respectively, there were total rains of 104.4, $112.2,75.4$ and $193.4 \mathrm{~mm}$. For the third cut, the volume of rain was lower and irrigation was essential to maintaining pasture development.

From the beginning of the experiment until the differentiation of the treatments (Figure 1), Tm and Rd values were lower due to the pasture sowing period. However, these variables increased in the periods between the first and the fourth cuts of the pastures. This tendency reflected in $\mathrm{ET}_{0}$ values, which showed variations especially when there were variations in Rd values. According to Fietz \& Fisch (2009) and Lemos Filho et al. (2010), among the meteorological elements (temperature, relative air humidity and wind speed), solar radiation is the factor that most influences the value of $\mathrm{ET}_{0}$.

Piatã fresh and dry matter yields were slightly superior to those of Mombaça at the four cuts, but it did not reflect in statistical difference between both pasture species (Table 1).
Table 1. Means of fresh and dry matter of the pastures Brachiaria brizantha cv. BRS Piatã and Panicum maximum cv. Mombaça for the four evaluated cuts

\begin{tabular}{|c|c|c|c|c|}
\hline \multirow{2}{*}{ Treatments } & \multicolumn{4}{|c|}{ Cut } \\
\hline & $1^{\text {st }}$ & $2^{\text {nd }}$ & $3^{\text {rd }}$ & $4^{\text {th }}$ \\
\hline & \multicolumn{4}{|c|}{ Fresh matter $\left(\mathrm{kg} \mathrm{ha}^{-1}\right)$} \\
\hline Mombaca & $7,928 \mathrm{a}$ & $16,624 \mathrm{a}$ & $24,717 \mathrm{a}$ & $21,894 \mathrm{a}$ \\
\hline \multirow[t]{2}{*}{ Piatã } & $9,250 \mathrm{a}$ & $17,702 \mathrm{a}$ & $25,607 \mathrm{a}$ & $22,209 a$ \\
\hline & \multicolumn{4}{|c|}{ Dry matter $\left(\mathrm{kg} \mathrm{ha}^{-1}\right)$} \\
\hline Mombaça & $1,807 \mathrm{a}$ & $3,034 \mathrm{a}$ & $4,450 \mathrm{a}$ & $4,087 \mathrm{a}$ \\
\hline Piatã & $1,952 \mathrm{a}$ & $3,276 \mathrm{a}$ & $4,576 \mathrm{a}$ & $4,105 a$ \\
\hline
\end{tabular}
probability level

Alencar et al. (2010), comparing the production of irrigated pastures from the genera Panicum and Brachiaria, in different periods of the year, also observed no significant statistical difference between the treatments; however, the Mombaça grass is taller and has lower amount of tillers in relation to Piatã.

According to the daily data of total dry matter yield of the four cuts, i.e., from sowing to the fourth cut (216 days), Mombaça and Piatã showed yields of 61.9 and $64.4 \mathrm{~kg} \mathrm{ha}^{-1} \mathrm{~d}^{-1}$, respectively. These values are close to those found by Alencar et. al. (2009a), who obtained mean yields of about 68 to $58 \mathrm{~kg} \mathrm{ha}^{-1} \mathrm{~d}^{-1}$ for the grasses Xaraés and Marandu, from the genus Brachiaria, and Tanzânia and Mombaça, from the genus Panicum.

The irrigation depths applied according to the treatments for the four evaluated cuts were expressed in terms of percentages of $\mathrm{ET}_{0}$ (Table 2). The amount of water applied to replenish $\mathrm{ET}_{0}$ (I3), except for the total applied in the period relative to the third cut $(91.2 \mathrm{~mm})$, was lower than the total rainfall, which shows the poor rainfall distribution in the region and the need for using irrigation to reduce drought effects, especially in regions with sandy-textured soils.

Fresh and dry matter yields as a function of the applied irrigation depths in terms of percentages of $\mathrm{ET}_{0}$, for the four pasture cuts, are shown in Figure 2. Since the interaction of Pasture species versus Irrigation depth was not statistically significant, the Overall Mean graphs represent fresh and dry matter yields of both pastures. However, for an individual analysis of the studied pastures, a follow-up analyses of irrigation depths were performed for each pasture species, represented by the graphs Piatã and Mombaça in Figure 2.

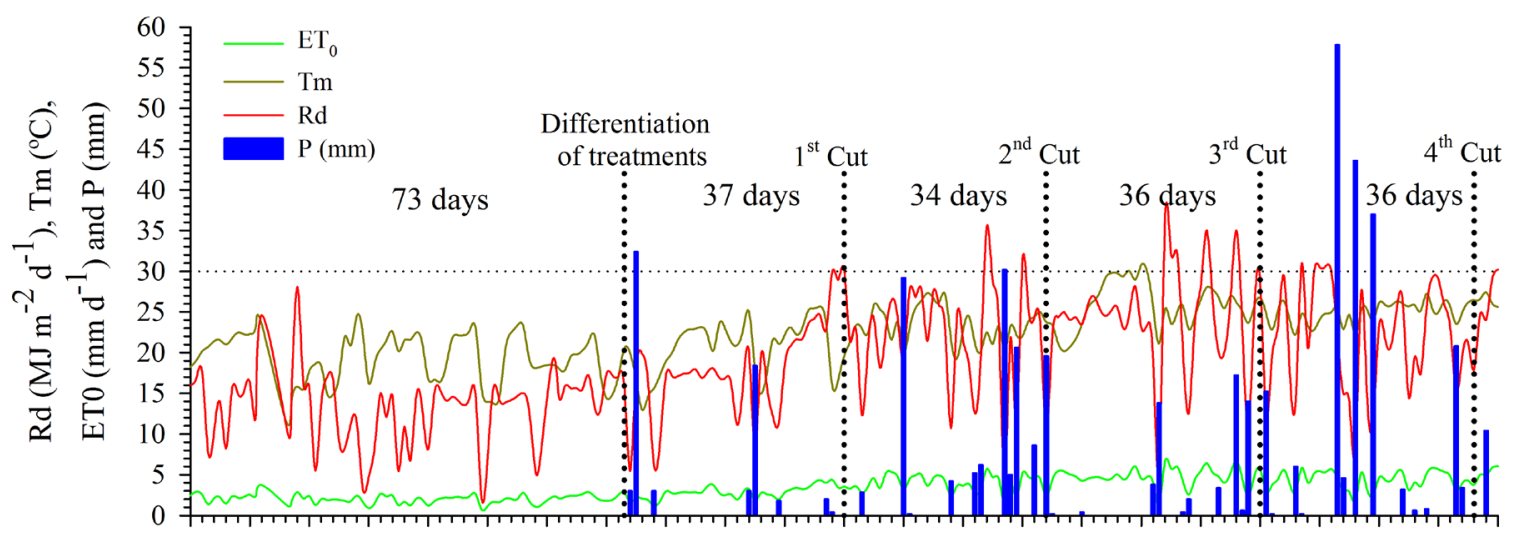

130140150160170180190200210220230240250260270280290300310320330340350

Number of the day in the year - $\mathrm{J}$

Figure 1. Variations of incident solar radiation $(\mathrm{Rd})$, mean air temperature $(\mathrm{Tm})$, reference evapotranspiration $\left(\mathrm{ET}_{0}\right)$ and rainfall $(\mathrm{P})$ along the experiment 
Table 2. Total water applied and percentage of reference evapotranspiration ( $\left.E T_{0}\right)$ for the different treatments of irrigation depth (I)

\begin{tabular}{|c|c|c|c|c|c|c|c|c|}
\hline \multirow{2}{*}{$\begin{array}{l}\text { Irrigation } \\
\text { depth }\end{array}$} & \multicolumn{2}{|c|}{$1^{1^{\mathrm{st}} \mathrm{Cut}}$} & \multicolumn{2}{|c|}{$2^{\text {nd }}$ Cut } & \multicolumn{2}{|c|}{$3^{\text {rd }}$ Cut } & \multicolumn{2}{|c|}{$4^{4^{\text {th }} \text { Cut }}$} \\
\hline & $\begin{array}{l}\text { Applied water } \\
(\mathbf{m m})\end{array}$ & $\% \mathrm{ET}_{0}$ & $\begin{array}{l}\text { Applied water } \\
(\mathrm{mm})\end{array}$ & $\% \mathrm{ET}_{0}$ & $\begin{array}{l}\text { Applied water } \\
\text { (mm) }\end{array}$ & $\% \mathrm{ET}_{0}$ & $\begin{array}{l}\text { Applied water } \\
(\mathrm{mm})\end{array}$ & $\% \mathrm{ET}_{0}$ \\
\hline 10 & 0 & 0 & 0 & 0 & 0 & 0 & 0 & 0 \\
\hline I1 & 13.4 & 20 & 4.8 & 8 & 24.9 & 27 & 29.6 & 36 \\
\hline 12 & 46.2 & 68 & 25.5 & 43 & 60.3 & 66 & 52.5 & 63 \\
\hline 13 & 68.2 & 100 & 59.4 & 100 & 91.2 & 100 & 83.0 & 100 \\
\hline 14 & 99.0 & 145 & 92.7 & 156 & 149.6 & 164 & 118.8 & 143 \\
\hline 15 & 134.2 & 197 & 128.3 & 216 & 183.1 & 201 & 140.4 & 169 \\
\hline
\end{tabular}
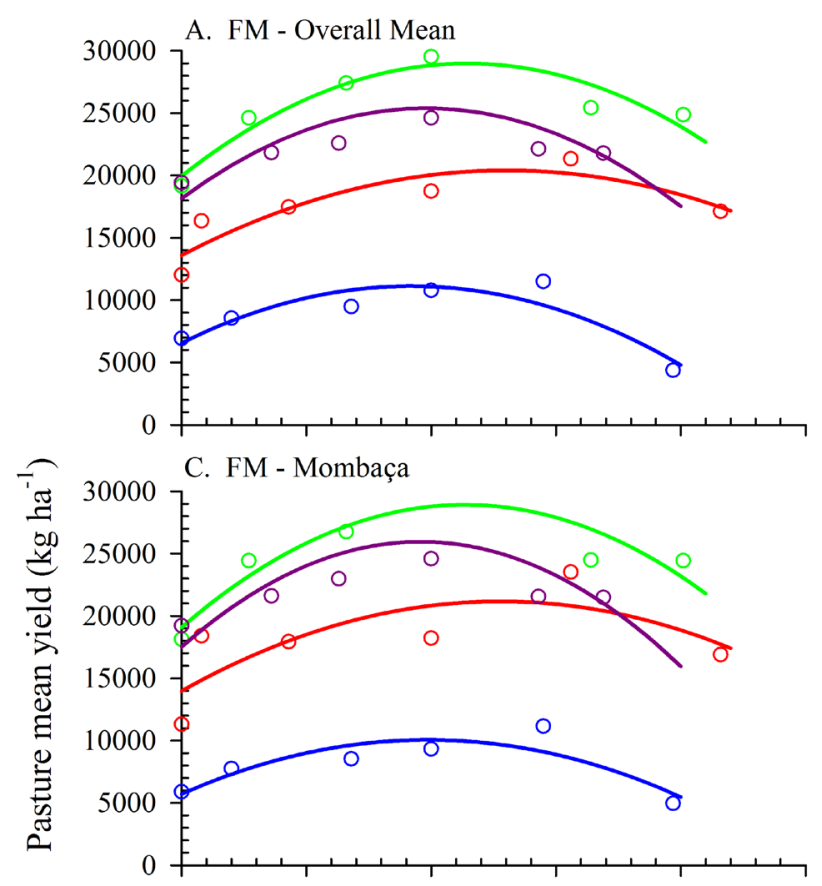

E. FM - Piatã

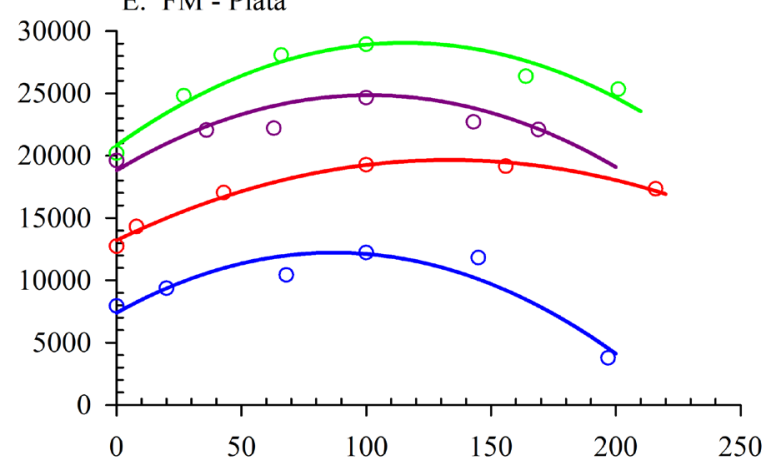

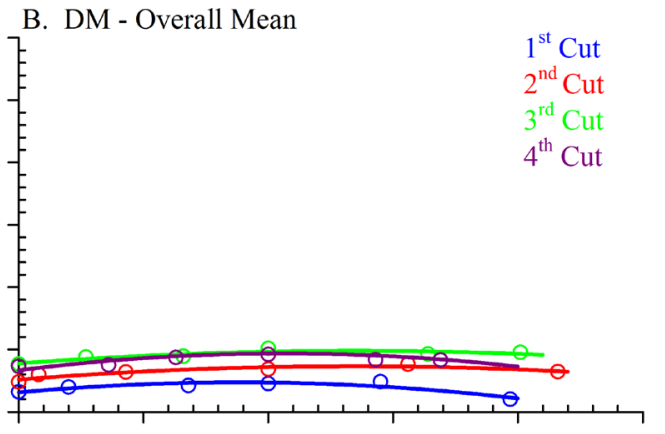

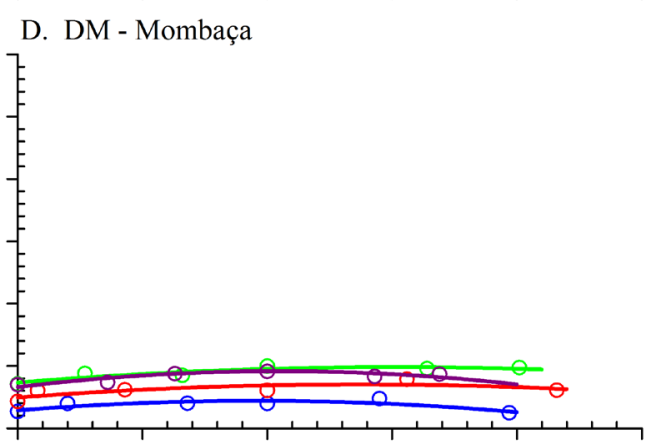

F. DM - Piatã

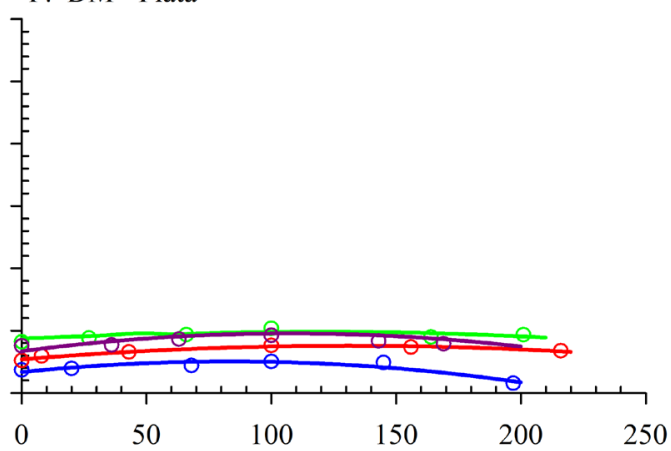

Applied water depth - \% of $\mathrm{ET}_{0}(\%)$

Figure 2. Fresh (FM) and dry (DM) matter yield as a function of the percentage of $\mathrm{ET}_{0}$ for the grasses Brachiaria brizantha cv. Piatã and Panicum maximum cv. Mombaça

The behavior of fresh and dry matter of the pastures, when the irrigation depths were applied, followed the quadratic model (Table 3$)$, statistically significant $(\mathrm{P}<0.05)$. The excessive application of water (I5) led to lower yields of both Piatã and Mombaça grasses at the first cut, in comparison to the treatment that did not receive water (I0) (Figure 2). For the other cuts, I0 was the treatment that promoted the lowest yields.

The points of maximum fresh and dry matter yield, as a function of irrigation depths, were estimated and are shown in Tables 4 and 5. In the comparison between irrigated and non-irrigated treatments (Table 5), the maximum dry matter yields were 52.1, 41.6, 26.2 and $25.1 \%$ higher under irrigation, respectively for the first, second, third and fourth cuts. According to NRC (1996), pastures with less than $2,000 \mathrm{~kg} \mathrm{ha}^{-1}$ of dry matter lead to lower consumption and increase in the grazing time. Thus, the use of irrigation can provide higher animal stocking in the grazing area and make livestock farming more intensive.

The percent values of $\mathrm{ET}_{0}$ that promoted the highest fresh and dry matter yields (Tables 4 and 5) represent the crop coefficients (Kc). Thus, for the periods comprehended between 73 and 110 (first cut), 110 and 144 (second cut), 144 and 180 (third cut) and 180 and 216 (fourth cut) days after sowing, respectively, mean Kc values were approximately of $0.9,1.33$, 1.24 and 1.02. At the first cut, the Kc value was lower, because 
Table 3. Regression equations and coefficients of determination $\left(R^{2}\right)$ of fresh and dry matter yields $\left(y\right.$, in $\left.k g a^{-1}\right)$ as a function of the percentage of $\mathrm{ET}_{0}(\mathrm{x}$, in \%) of the pastures Brachiaria brizantha cv. BRS Piatã and Panicum maximum cv. Mombaça

\begin{tabular}{|c|c|c|c|c|c|}
\hline \multirow{2}{*}{ Cut } & \multirow{2}{*}{$\begin{array}{c}\text { Irrigation } \\
\text { depth }\end{array}$} & \multicolumn{2}{|l|}{ Fresh matter (kg ha-1) } & \multicolumn{2}{|l|}{ Dry matter (kg ha-1) } \\
\hline & & Equation & $\mathbf{R}^{2}$ & Equation & $\mathbf{R}^{2}$ \\
\hline \multirow{3}{*}{$1^{\text {st }}$} & Overall mean & $y=-0.541 x^{2}+99.5 x+6557$ & 0.819 & $y=-0.103 x^{2}+18.3 x+1556$ & 0.825 \\
\hline & Mombaça & $y=-0.446 x^{2}+88.1 x+5719$ & 0.734 & $y=-0.084 x^{2}+16.1 x+1435$ & 0.688 \\
\hline & Piatã & $y=-0.636 x^{2}+110.8 x+7396$ & 0.868 & $y=-0.123 x^{2}+20.5 x+1678$ & 0.854 \\
\hline \multirow{3}{*}{$2^{\text {nd }}$} & Overall mean & $y=-0.402 x^{2}+104.7 x+13593$ & 0.798 & $y=-0.059 x^{2}+16.0 x+2584$ & 0.842 \\
\hline & Mombaça & $y=-0.441 x^{2}+112.6 x+13979$ & 0.545 & $y=-0.056 x^{2}+15.4 x+2466$ & 0.592 \\
\hline & Piatã & $y=-0.363 x^{2}+96.76 x+13206$ & 0.983 & $y=-0.063 x^{2}+16.6 x+2701$ & 0.962 \\
\hline \multirow{3}{*}{$3^{\text {rd }}$} & Overall mean & $y=-0.690 x^{2}+157.9 x+19950$ & 0.892 & $y=-0.056 x^{2}+15.1 x+3880$ & 0.798 \\
\hline & Mombaça & $y=-0.764 x^{2}+173.5 x+19079$ & 0.838 & $y=-0.053 x^{2}+16.3 x+3672$ & 0.818 \\
\hline & Piatã & $y=-0.616 x^{2}+142.4 x+20822$ & 0.934 & $y=-0.058 x^{2}+13.9 x+4088$ & 0.675 \\
\hline \multirow{3}{*}{$4^{\text {th }}$} & Overall mean & $y=-0.444 x^{2}+88.26 x+19294$ & 0.876 & $y=-0.078 x^{2}+16.6 x+3521$ & 0.774 \\
\hline & Mombaça & $y=-0.497 x^{2}+95.45 x+19090$ & 0.860 & $y=-0.073 x^{2}+17.2 x+3406$ & 0.786 \\
\hline & Piatã & $y=-0.391 x^{2}+81.07 x+19498$ & 0.858 & $y=-0.083 x^{2}+16.0 x+3636$ & 0.738 \\
\hline
\end{tabular}

Table 4. Maximum fresh matter yield of the pastures Brachiaria brizantha cv. Piatã and Panicum maximum cv. Mombaça, for the four evaluated cuts

\begin{tabular}{|c|c|c|c|c|c|c|c|c|}
\hline \multirow{2}{*}{$\begin{array}{l}\text { Irrigation } \\
\text { depth }\end{array}$} & \multicolumn{2}{|c|}{$1^{\text {st }}$ cut } & \multicolumn{2}{|c|}{$2^{\text {nd }}$ cut } & \multicolumn{2}{|c|}{$3^{\text {rd }}$ cut } & \multicolumn{2}{|c|}{$4^{\text {th }}$ cut } \\
\hline & $\begin{array}{c}\% \mathrm{ET}_{0} \\
(\%)\end{array}$ & $\begin{array}{c}y \\
\left(\mathrm{~kg} \mathrm{ha}^{-1}\right)\end{array}$ & $\begin{array}{c}\% \mathrm{ET}_{0} \\
(\%)\end{array}$ & $\begin{array}{c}y \\
\left(\mathrm{~kg} \mathrm{ha}^{-1}\right)\end{array}$ & $\begin{array}{c}\% \mathrm{ET}_{0} \\
(\%)\end{array}$ & $\begin{array}{c}y \\
\left(\mathrm{~kg} \mathrm{ha}^{-1}\right)\end{array}$ & $\begin{array}{c}\text { \%ET }_{0} \\
(\%)\end{array}$ & $\begin{array}{c}y \\
\left(\mathrm{~kg} \mathrm{ha}^{-1}\right)\end{array}$ \\
\hline Overall mean & 91.9 & 11,128 & 130.2 & 20,410 & 114.4 & 28,983 & 99.4 & 23,680 \\
\hline Mombaça & 98.8 & 10,068 & 127.7 & 21,166 & 113.5 & 28,929 & 96.0 & 23,673 \\
\hline Piatã & 87.1 & 12,221 & 133.3 & 19,654 & 115.6 & 29,052 & 103.7 & 23,700 \\
\hline
\end{tabular}

Table 5. Maximum dry matter yield of the pastures Brachiaria brizantha cv. Piatã e Panicum maximum cv. Mombaça, for the four evaluated cuts

\begin{tabular}{|c|c|c|c|c|c|c|c|c|}
\hline \multirow[b]{2}{*}{$\begin{array}{l}\text { Irrigation } \\
\text { depth }\end{array}$} & \multicolumn{2}{|c|}{$1^{\text {st }}$ cut } & \multicolumn{2}{|c|}{$2^{\text {nd }}$ cut } & \multicolumn{2}{|c|}{$3^{\text {rd }}$ cut } & \multicolumn{2}{|c|}{$4^{\text {th }}$ cut } \\
\hline & $\begin{array}{c}\text { \%ET }_{0} \\
\text { (\%) }\end{array}$ & $\begin{array}{c}y \\
\left(\mathrm{~kg} \mathrm{ha}^{-1}\right)\end{array}$ & $\begin{array}{c}\% \mathrm{ET}_{0} \\
(\%)\end{array}$ & $\begin{array}{c}y \\
\left(\mathrm{~kg} \mathrm{~h}^{-1}\right)\end{array}$ & $\begin{array}{c}\text { \%ET }_{0} \\
(\%)\end{array}$ & $\begin{array}{c}y \\
\left(\mathrm{~kg} \mathrm{ha}^{-1}\right)\end{array}$ & $\begin{array}{c}\text { \%ET }_{0} \\
(\%)\end{array}$ & $\begin{array}{c}\mathrm{y} \\
\left(\mathrm{kg} \mathrm{ha}^{-1}\right)\end{array}$ \\
\hline Overall mean & 88.7 & 2,367 & 135.6 & 3,668 & 134.8 & 4,898 & 106.5 & 4,405 \\
\hline Mombaça & 95.7 & 2,205 & 137.7 & 3.527 & 153.7 & 4,927 & 117.7 & 4,418 \\
\hline Piatã & 83.3 & 2,531 & 131.7 & 3.793 & 119.7 & 4,918 & 96.6 & 4.411 \\
\hline
\end{tabular}

the pastures were in the initial development stage and mean temperature and incident solar radiation were lower. However, for the other cuts, with the increase in mean air temperature and incident radiation and the development of the pastures, the Kc value was higher.

The Kc values for Mombaça and Piatã grasses in the present study are above the single, constant value of 0.8 ,

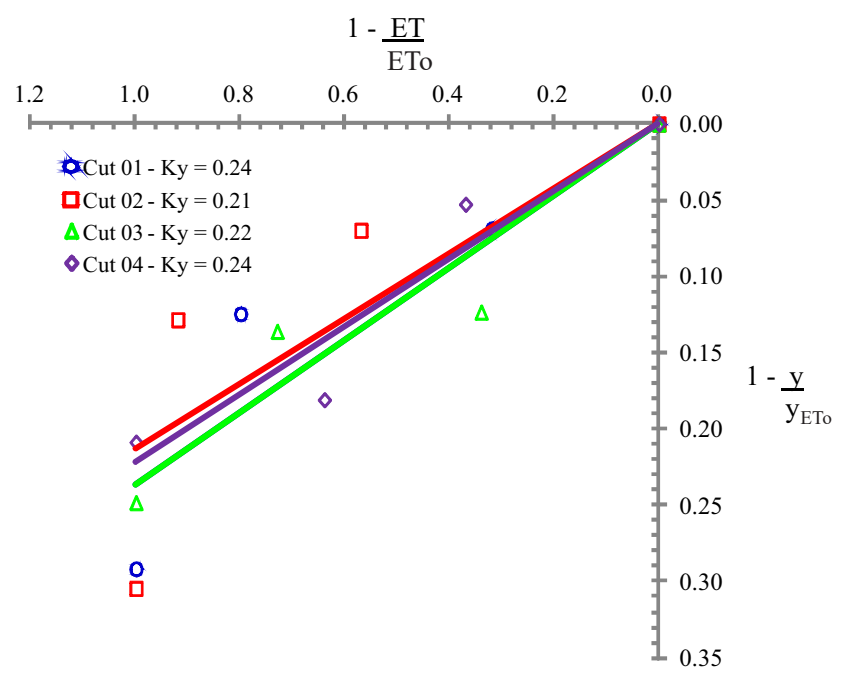

Figure 3. Yield response factor (Ky) of the pastures Brachiaria brizantha cv. Piatã and Panicum maximum cv. Mombaça for the four evaluated cuts recommended by Alencar et al. (2009b). Therefore, with the lack of information for irrigation management in pastures, recommendations of single Kc values, close to 1.0, promoted the higher pasture yields compared with the value suggested by Alencar et al. (2009b).

The dry matter yield reduction of the pastures in relation to the reduction in $\mathrm{ET}_{0}$ is shown in Figure 3; the slopes of the lines represent the yield response factors (Ky), which varied from 0.21 to 0.24 . According to Doorenbos \& Kassan (1979), this relationship allows the estimation of the impact of irrigation management on crop economic production and helps in the selection of management strategies. Therefore, for the studied pastures, a decrease of $50 \%$ in the application of water would lead to a reduction of $12 \%$ in pasture dry matter yield.

\section{Conclusions}

1. There was no difference in fresh and dry matter yields between the studied pastures.

2. Irrigation promoted increase in the yield of the studied pastures, regardless of the period of cut.

\section{ACknowledgments}

To the Coordination for the Improvement of Higher Education Personnel (CAPES) and the Institutional Program 
of Scientific Initiation Scholarships (PIBIC/CNPq-FA-UEM), for granting the scholarships.

\section{Literature Cited}

Alencar, C. A. B.; Cóser, A. C.; Oliveira, R. A.; Martins, C. E.; Cunha, F. F.; Figueiredo, J. L. A. Produção de seis gramíneas manejadas por corte sob efeito de diferentes lâminas de irrigação e estações anuais. Ciência e Agrotecnologia, v.33, p.1307-1313, 2009a. http:// dx.doi.org/10.1590/S1413-70542009000500016

Alencar, C. A. B.; Cunha, F. F.; Martins, C. E.; Cóser, A. C.; Rocha, W. S. D.; Araújo, R. A. S. Irrigação de pastagem: Atualidade e recomendações para uso e manejo. Revista Brasileira de Zootecnia, v.38, p.98-108, 2009b. http://dx.doi.org/10.1590/ S1516-35982009001300012

Alencar, C. A. B. D.; Oliveira, R. A. D.; Cóser, A. C.; Martins, C. E.; Figueiredo, J. L. A.; Cunha, F. F. D.; Leal, B. G. Produção de seis capins manejados por pastejo sob efeito de diferentes doses nitrogenadas e estações anuais. Revista Brasileira de Saúde e Produção Animal, v.11, p.48-58, 2010.

Alvares, J. A. S. Caracterização e análise zootécnica e financeira de um sistema de produção de leite com pastagens tropicais irrigadas na microrregião de Governador Valadares, Minas Gerais. Belo Horizonte: UFMG, 2001. 75p. Doctoral Thesis

Cunha, F. F.; Soares, A. A.; Pereira, O. G.; Lambertucci, D. M.; Abreu, F. V. S. Características morfogênicas e perfilhamento do Panicum maximum Jacq. cv. Tanzânia irrigado. Ciência e Agrotecnologia, v.31, p.628-635, 2007. http://dx.doi.org/10.1590/ S1413-70542007000300005

Doorenbos, J; Kassam, A. H. Yield response to water. Rome: FAO, 1979. 193p. (FAO, Irrigation and Drainage Paper, 33).

Ferreira, D. F. Sisvar: A computer statistical analysis system. Ciência e Agrotecnologia, v.35, p.1039-1042, 2011.

Fietz, C. R.; Fisch, G. F. Avaliação de modelos de estimativa do saldo de radiação e do método de Priestley-Taylor para a região de Dourados, MS. Revista Brasileira de Engenharia Agrícola e Ambiental, v.13, p.449-453, 2009. http://dx.doi.org/10.1590/ S1415-43662009000400012
Lemos Filho, L. C. A.; Carvalho, L. G.; Evangelista, A. W. P.; Alves Júnior, J. Análise espacial da influência dos elementos meteorológicos sobre a evapotranspiração de referência em Minas Gerais. Revista Brasileira de Engenharia Agrícola e Ambiental, v.14, p.1294-1303. 2010. http://dx.doi.org/10.1590/S1415-43662010001200007

Gomes, E. P.; Rickli, M. E.; Cecato, U.; Vieira, C. V.; Sapias, J. G.; Sanches, A. C. Produtividade do capim Tifton 85 sob irrigação e doses de nitrogênio. Revista Brasileira de Engenharia Agrícola e Ambiental, v.19, p.317-323. 2015. http://dx.doi.org/10.1590/18071929/agriambi.v19n4p317-323

Müller, M. S.; Fancelli, A. L.; Dourado Neto, D.; García, A.; Ovejero, R. F. L. Produtividade do Panicum maximum cv. Mombaça irrigado, sob pastejo rotacionado. Scientia Agricola, v.59, p.427-433, 2002. http://dx.doi.org/10.1590/S0103-90162002000300003

NRC - National Research Council. Nutrient requirements of beef cattle. 7.ed. Washington: National Academy Press, 1996. 234p.

Oliveira, E. L. Sugestão de adubação e calagem para culturas de interesse econômico no Estado do Paraná. Londrina: IAPAR, 2003. 30p.

Ribeiro, E. G.; Fontes, C. D. A.; Palieraqui, J. G. B.; Cóser, A.; Martins, C. E.; Silva, R. D. Influência da irrigação, nas épocas seca e chuvosa, na produção e composição química dos capins napier e mombaça em sistema de lotação intermitente. Revista Brasileira de Zootecnia, v.38, p.1432-1442, 2009. http://dx.doi.org/10.1590/ S1516-35982009000800006

Sanches, A. C.; Gomes, E. P.; Rickli, M. E.; Fasolin, J. P.; Soares, M. R. C.; Goes, R. H. T. B. Produtividade e valor nutritivo do capim Tifton 85 irrigado e sobressemeado com aveia. Revista Brasileira de Engenharia Agrícola e Ambiental, v.19, p.126-133. 2015. http:// dx.doi.org/10.1590/1807-1929/agriambi.v19n2p126-133

Santos, M. E. R.; Fonseca, D. D.; Euclides, V. P. B.; Ribeiro Júnior, J. I.; Nascimento Júnior, D. D.; Moreira, L. D. M. Produção de bovinos em pastagens de capim-braquiária diferidas. Revista Brasileira de Zootecnia, v.38, p.635-642, 2009. http://dx.doi.org/10.1590/ S1516-35982009000400007

Vitor, C. M. T.; Fonseca, D. M.; Cóser, A. C.; Martins, C. E.; Nascimento Júnior, D.; Ribeiro Júnior, J. I. Produção de matéria seca e valor nutritivo de pastagem de capim-elefante sob irrigação e adubação nitrogenada. Revista Brasileira de Zootecnia, v.38, p.435-442, 2009. http://dx.doi.org/10.1590/S1516-35982009000300006 